\title{
Effects of polyphenol and anthocyanin contents of Punica granatum fruit parts on their antioxidant and anticancer activities
}

\author{
Jung-Suk Park ${ }^{1}$, Sang-Uk Chon ${ }^{2}$, Eun Woo Moon ${ }^{3}$, Cheol-Yun Jeong ${ }^{1 *}$ \\ ${ }^{1}$ Department of Alternative Medicine, Kwang-ju Women's University, Gwangju 62396, Korea \\ ${ }^{2}$ Future Agro-Food Research Institute, EFARINET Co., Ltd., Gwangju 61071, Korea \\ ${ }^{3}$ Department of Food and Nutrition, Hanyang University, Seoul 04763, Korea
}

\section{석류 과실 부위별 폴리페놀 및 안토시아닌 함량이 항산화 및 항암 활성에 미치는 영향}

\author{
박정숙 $^{1} \cdot$ 천상욱 $^{2} \cdot$ 문은우 $^{3} \cdot$ 정철윤 $^{1 *}$ \\ ${ }^{1}$ 광주여자대학교, ${ }^{2}$ (주)이파리넷, ${ }^{3}$ 한양대학교
}

\begin{abstract}
The purpose of this study was to determine the content of phenolics and various anthocyanin compounds, and antioxidant and anticancer activities of the extracts from pomergranates, which were produced in two different regions including Goheung, Korea and California, USA. These pomergrantes were divided into juice, pericarp, and seed parts and each part was extracted with $\mathbf{9 5 \%}$ methanol. Content of total phenolics [mg chlorogenic acid equivalents/kg DW] was highest in pericarp, followed by juice and seeds from pomergrantes in both regions. The anthocyanins identified in pomegranate fruit were cyanidin-3,5-diglucoside chloride $(\mathrm{Cy3}, 5 \mathrm{G})$, cyanidin-3-O-glucoside chloride (Cy3G), delphini din-3,5-di-O-glucoside chloride (Dp3,5G), delphinidin-3-O-glucoside chloride (Dp3G), pelargonidin3,5-di-glucoside chloride (Pg3,5G), and pelargonidin-3-glucoside chloride (Pg3G). Among these, cyanidin-3, 5-diglucoside chloride $(\mathrm{Cy} 3,5 \mathrm{G})$ was the major anthocyanin in California pomegranate fruit juice and Goheung pomegranate fruit pericarp. DPPH (1,1-diphenyl-2-picryl hydrazyl radical) free radical scavenging activity was dose-dependently increased, and was higher in pericarp part than juice or seed parts from pomergrantes in both regions. By MTT (3-(4,5-dimethylthiazol-2-yl)-2,5-diphenyl tetrazolium bromide) assay, pericarp extracts from pomergrantes in both regions showed the highest anticancer activity, which was higher on Calu-6 for human pulmonary carcinoma than SNU-601 for human gastric carcinoma. Correlation between polyphenols and anticancer activity on Calu- 6 was determined to be in the range of $r^{2}=0.8904$ to 0.9706 .
\end{abstract}

Key words : Punica granatum, polyphenol, anthocyanin, DPPH radical scavenging activity, anticancer activity

\begin{abstract}
서 론
석류(石榴; pomegranate; Punica granatum L.)는 석류나무 과에 속하는 낙엽 소교목으로 원산지는 이란, 이스라엘,
\end{abstract}

*Corresponding author. E-mail : cyjeong@mail.kwu.ac.kr Phone : 82-62-950-3736, Fax : 82-62-950-3661

Received 30 October 2015; Revised 8 December 2015; Accepted 3 June 2016.

Copyright (c) The Korean Society of Food Preservation. All rights reserved.
터키, 그리스, 이탈리아, 스페인으로 현재 히말라야 주변의 인도와 중국을 거쳐 일본, 한반도까지 재배되고 있으며(1), 우리나라에서는 주로 전라남도 고흥군에서 과수원 형태로 재배되고 있으며 재배 품종은 그 맛에 따라 신석류(신맛이 강한 산과), 단석류(단맛이 강한 감과)로만 구분되고 있 다(2).

최근 석류의 부위에 따른 항산화 물질 및 항산화 효능에 관한 연구결과에 의하면 씨나 과육에 비해 껍질에 total phenolics, flavonoids, proanthocyanidins와 같은 천연 항산 화 물질이 풍부하고 FRAP, DPPH, $\beta$-carotene linoleate, 
$\mathrm{CuSO}_{4}$ 에 의한 $\mathrm{LDL}$ 산화법 등의 in vitro 항산화 효과를 보였으며 $(3,4)$, 석류껍질에 항산화 및 항 돌연변이 효과가 뛰어나다고 보고되어 있다(5).

과실 주스(juice)는 예로부터 강장제로 알려져 왔으며(6) 석류 과실에는 사과산, 구연산 등의 유기산과 항산화성 기 능성 소재인 엘라긴산(ellagic acid)을 생성하는 탄닌질이 함유되어 있으며, 엘라긴산은 지금까지 알려진 어느 암 예 방 물질보다도 가장 우수한 항암효과를 갖는 천연물질로 알려지고 있다(7). 국내에서 생산되는 석류는 생산량이 적 고 당도가 낮아 대부분의 석류가공품들은 일본, 미국, 이란 에서 수입한 석류 농축액을 주로 사용하고 있다(8). 주스는 천연에서 가장 강력한 항산화제 중의 하나이며, 동맥경화 성의 병반을 분해하는 강력한 성질이 있다. 특히, 주스는 청량제, 혈액 토닉으로 사용되고 있는데, anthocyanin은 강 력한 항산화성 flavonoid가 주성분이며 주스의 번쩍이는 색깔은 성숙과정에서 점차 더 많이 침착되나 압착 추출 후에는 감소된다(9). 주스에는 $\mathrm{Fe}$ 이 많이 함유되어 있으며, $\mathrm{Ca}, \mathrm{Ce}, \mathrm{Cl}, \mathrm{Co}, \mathrm{Cu}, \mathrm{K}, \mathrm{Mg}, \mathrm{Mn}, \mathrm{Mo}, \mathrm{Na}, \mathrm{Rb}, \mathrm{Se}, \mathrm{Sn}, \mathrm{Sr}$, $\mathrm{Zn}$ 등도 미량 함유되어 있다(10).

외과피(pericarp)는 설사, 이질, 복통, 대하증, 수축제(收 縮劑), 각종 기생충 구제약 등으로 사용하여 왔다(11). 외과 피는 $\operatorname{tannin} 10.421 .3 \%$, 수지 $4.5 \%$, gallic acid $4.0 \%$, 고무질 $3.2 \%$, 당 $2.7 \%$, mannitol $1.8 \%$, inulin $1.0 \%$, 납 $0.8 \%$, 점액질 $0.6 \%$, malic acid, pectin, calcium oxalate, isoquercitrin을 함 유하며(12), 약리작용으로는 구충·항균·항바이러스·수태 율 감소·혈액응고 촉진·항산화 $(13,14)$ 등이 있다. 탄닌과 flavonoid는 재배한 것보다 야생석류의 외과피에 더 많이 함유되어 있는 것으로 보고되어 있다(15). 가수분해성 탄닌 으로 punicalagin과 punicalin, 탄닌산으로 gallic acid, ellagic acid(EA), flavone으로 luteolin, quercetin, flavonol으로 kaempferol, flavonone으로 naringenin 등이 있으나 부분적 으로 복합당질도 함유되어 있다(16).

종자(seed)에는 천연식물성 여성 호르몬(estrogen)의 전 구물질(17)과 칼륨, 비타민 $\mathrm{B}_{1}, \mathrm{~B}_{2}$, 나이아신이 비교적 많이 함유되어 있으며 생리활성이 강한 polyphenol과 tannin을 많이 함유하고 있어 기능성 식품으로 주목받고 있다(18). 특히, tannin이 많아 수렴성 건위약으로 쓰여 왔다(19). 또한 종자에는 지방산 성분이 $95 \%$ 이상이며, 그 중 $99 \%$ 는 중성 지방으로 종자 중량의 $12 \sim 20 \%$ 를 차지한다. 주된 지방산은 conjugated octadecatrienoic acid로써 punicic acid가 약 $65.3 \%$, palmitic acid $4.8 \%$, stearic acid $2.3 \%$, oleic acid $6.3 \%$, linoleic acid $6.6 \%$, 미동정물질 $14.2 \%$ 가 함유되어 있으나 (20), 그 미동정 물질 가운데 하나가 a-eleaosteric acid로 약 $5 \%$ 함유되어 있음이 새롭게 확인되었다 $(21,22)$. 발효 종자의 chloroform 획분에는 1-O-trans, cis-, trans-9,11,13octadecatrienoyl glycerol, 1-O-isopentyl-3-O-octadec- 2-enoyl glycerol, cis-9-octadecenoic, octadecanoic 및 eicosanoic acid
등이 LC/MS에서 검출되었다(23).

석류 품종 "Assaria" 및 "Wonderful" 주스에는 anthocyanidin 으로 항산화 성분인 cyanidin-3,5-diglucoside chloride(Cy3, $5 \mathrm{G})$, cyanidin-3-O-glucoside chloride(Cy3G), delphinidin-3, 5-di-O-glucoside chloride(Dp3,5G), delphinidin-3-O- glucosidechloride(Dp3G), pelargonidin-3,5-di-glucoside chloride( $\mathrm{Pg} 3$, $5 \mathrm{G})$, pelargonidin-3-glucoside chloride $(\mathrm{Pg} 3 \mathrm{G})$ 등이 검출되 었다 $(9,24)$.

석류 과실 내외부의 부위별 유효성분 및 효능 차이를 알아보기 위해 본 연구에서는 신석류인 고흥산과 단석류인 캘리포니아산 석류를 공시하여 석류 과실의 외과피, 주스 및 종자의 폴리페놀 함량, 안토시아닌 함량, 항산화성 및 항암성 차이를 검토하였다.

\section{재료 및 방법}

\section{메탄올 추출물 조제}

고흥산 신석류와 캘리포니아산 단석류를 구입하여 외과 피, 과육 및 종자 부분으로 나눈 후 $-60^{\circ} \mathrm{C}$ 하에서 5 일간 동결 건조(SFDSM24, SAMWON ENG, Busan, Korea) 하였다. 건조된 시료를 마쇄하여 $1 \mathrm{~mm}$ 체에 통과시킨 후 시료 당 $200 \mathrm{~g}$ 을 95\% methanol $2 \mathrm{~L}$ 에 24시간 동안 추출하여 여과한 후 그 추출액을 $50^{\circ} \mathrm{C}$ 에서 감압농축기 $(\mathrm{N}-1000 \mathrm{~S}-\mathrm{WCCA}-$ 1100 , Eyela, Tokyo, Japan)하여 methanol 추출물을 얻어 동결 건조하여 사용하였다.

\section{총 페놀성 화합물 함량}

총 페놀성 화합물 함량은 Folin-Denis 방법(25)에 따라 분석하였다. 추출물을 $1 \mathrm{mg} / \mathrm{mL}$ 농도로 조제한 후, 이 시료 액 $1 \mathrm{~mL}$ 에 증류수 $3 \mathrm{~mL}$ 를 첨가하고, Folin \& Ciocalteau's phenol reagent(Sigma Co., St. Louis, MO, USA) $1 \mathrm{~mL}$ 를 첨가한 후 $27^{\circ} \mathrm{C}$ Shaking bath(HB 203S, Han Baek Scientific Co., Bucheon, Korea)에서 혼합하였다. 5 분 후 $\mathrm{NaCO}_{3}$ 포화 용액 $1 \mathrm{~mL}$ 를 넣어 혼합하여 실온에서 1 시간 방치한 후 $640 \mathrm{~nm}$ 에서 분광광도계(UV-1650PC, SHIMADZU, Kyoto, $\mathrm{Japan)}$ 로 흡광도를 측정하였다. 페놀 화합물 함량은 표준물질 chlorogenic acid, tannic acid 및 catechin(Sigma Co., St. Louis, $\mathrm{MO}, \mathrm{USA})$ 의 농도를 이용하여 검량선을 작성한 후 정량하 였다.

\section{안토시아닌 함량}

석류의 안토시아닌 함량은 Hiemori 등의 방법(26)에 따 라 분석되었다. 동결건조하여 분쇄한 시료 $0.5 \mathrm{~g}$ 을 칭량하 여 메탄올과 $1.0 \mathrm{~N}$ 염산용액 혼합액(85:15, v/v) $8 \mathrm{~mL}$ 를 첨가하고 MS-300HS plate(Misung Scientific Co., Ltd., Seoul, Korea)를 이용하여 30 분 동안 추출하였다. 추출액은 
$4{ }^{\circ} \mathrm{C}$ 로 설정된 $4,500 \times \mathrm{g}$ 에서 20 분 동안 원심분리하여 상징액 을 농축플라스크로 옮기고, 남은 시료는 위와 동일한 방법 으로 두 번 더 추출하였다. 모은 상징액을 진공농축기 (EYELA, Rikakikai Co., Tokyo, Japan)를 이용하여 2 3 mL 까지 농축하였다. 농축액은 메탄올과 $1.0 \mathrm{~N}$ 염산용액 혼합 액(85:15, v/v)으로 $10 \mathrm{~mL}$ 로 정용한 후 $0.45 \mu \mathrm{m} \mathrm{Millex-FH}$ hydrophobic fluoropure(PTFE) membrane(Millipore, Milford, MA, USA)으로 여과하였다. HPLC는 2998 photodiode array detector(Waters Corporation, Milford, MA, USA)가 장착된 Waters Alliance 2690 HPLC system(Waters Corporation, Milford, MA, USA)을 사용하였으며, 분석칼럼은 Zorbax ODS column $(5 \mu \mathrm{m}, 250 \times 4.6 \mathrm{~mm}$ i.d., Agilent, Palo Alto, $\mathrm{CA}, \mathrm{USA})$ 을 이용하였다. 안토시아닌 분리는 이동상 용매 $\mathrm{A}(0.2 \mathrm{M}$ o-phosphoric acid, $\mathrm{pH} 1.5)$ 와 용매 $\mathrm{B}(80 \%$ acetonitrile/20\% $0.2 \mathrm{M}$ o-phosphoric acid, $\mathrm{pH} 1.5$ )를 다음과 같은 농도 구배 조건으로 총 55 분에 걸쳐 시행하였다. 이동 상 용매 $\mathrm{A}$ 와 $\mathrm{B}$ 의 비율은, $100 \%$ 용매 $\mathrm{A}$ 를 시작으로 하여 4 분까지 $92 \%$ 로, 이 후 10 분까지 $86 \%, 30$ 분까지 $83.5 \%, 35$ 분 까지 $74 \%, 55$ 분까지 $20 \%$ 로 단계적으로 낮추면서, 용매 $\mathrm{B}$ 의 비율을 상대적으로 증가시켰다. 이동상의 유속은 1 $\mathrm{mL} / \mathrm{min}$, ultraviolet-visible detector의 파장은 $520 \mathrm{~nm}$ 에서 시행하였다. 시료의 안토시아닌 피크는 크로마토그램에서 검출된 시간과 UV-Vis 스펙트럼을 표준물질의 피크와 비 교하여 확인하였다(Fig. 1). 안토시아닌 화합물인 $\mathrm{Cy} 3,5 \mathrm{G}$, $\mathrm{Cy} 3 \mathrm{G}, \mathrm{Dp} 3,5 \mathrm{G}, \mathrm{Dp} 3 \mathrm{G}, \mathrm{Pg} 3,5 \mathrm{G}, \mathrm{Pg} 3 \mathrm{G}$ 의 표준용액은 주입된 $10 \mu \mathrm{L}$ 에 5 200 $\mu \mathrm{g}$ 범위에서 직선상을 나타냈다. 총 안토시 아닌 함량은 샘플 내 각 개별 안토시아닌 함량을 합산하여 구하였다.

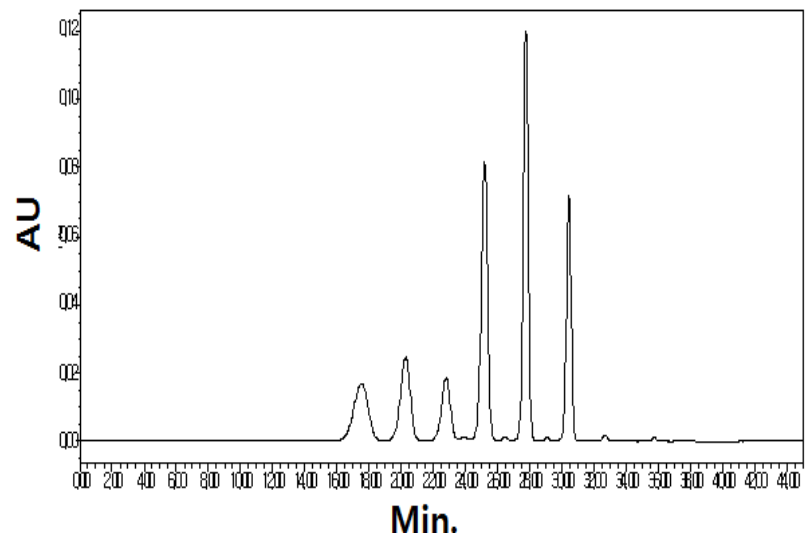

Fig. 1. Chromatogram of anthocyanins as standards, peak 1 to 6 , from a pomegranate sample.

Peak identities: Cyanidin-3,5-diglucoside chloride (Cy3,5G), Cyanidin-3-O-glucoside chloride (Cy3G), Delphinidin-3,5-di-O-glucoside chloride (Dp3,5G), Delphinidin-30-glucoside chloride (Dp3G), Pelargonidin-3,5-di-glucoside chloride (Pg3,5G), and Pelargonidin-3-glucoside chloride ( $\mathrm{Pg} 3 \mathrm{G})$. Identity of the other peaks is unknown.

\section{$\mathrm{DPPH}$ 라디컬 소거능}

HPLC에 의해 DPPH(1,1-diphenyl-2-picryl hydrazyl radical) scavenging activity 검정 방법(27)으로서 분석대상이 $\mathrm{DPPH}$ 용액의 흡광도 $(500 ~ 550 \mathrm{~nm})$ 와 같은 영역에 있을 경우 HPLC(HPLC system, SHIMADZU, Kyoto, Japan)를 이용하 여 정량적 분석조건이 가능하다. $900 \mu \mathrm{L} \mathrm{DPPH}$ 용액(100 $\mu \mathrm{M})$ 과 시료용액 $100 \mu \mathrm{L}$ 을 혼합한 후 암조건에서 10 분 동안 반응시켰다. $900 \mu \mathrm{L} \mathrm{DPPH}$ 용액 $(100 \mu \mathrm{M})$ 과 시료추출물의 용해한 용액 $(100 \mu \mathrm{L})$ 을 혼합하여 상기방법으로 측정하여 시료가 첨가하지 않은 DPPH용액(무처리구)의 용출 peak의 면적으로 계산하였다. 시료의 DPPH radical-scavenging 활 성은 ascorbic acid(대조구)와 비교하였다. Column: Shim $\operatorname{pack}(4.6 \times 250 \mathrm{~mm})$, mobile phase: $\mathrm{MeOH}-\mathrm{H}_{2} \mathrm{O}(70: 30, \mathrm{v} / \mathrm{v})$, wavelength: $517 \mathrm{~nm}$, flow rate: $0.8 \mathrm{~mL} / \mathrm{min}$, attenuation: 32 , injection volume: $20 \mu \mathrm{L}$ 의 HPLC 조건으로 실시하며 HPLC 에 의한 DPPH radical-scavenging 활성은 다음과 같이 구하 였다.

$\mathrm{A} n=(\mathrm{A}-\mathrm{Ao}) / \mathrm{Ao} \times 100$

$\mathrm{A} n$ : DPPH radical-scavenging 활성 (\%)

$\mathrm{A}$ : 시료가 첨가된 반응용액 중의 $\mathrm{DPPH}$ radical의 용출피 크면적

Ao : 시료가 첨가되지 않은 DPPH radical 용액의 용출피 크면적

필요에 따라 각 식물체의 메탄올 추출물을 처리하여 $\mathrm{DPPH}$ 라디칼을 $50 \%$ 소거하는 시료의 농도를 $\mathrm{IC}_{50}$ 또는 $\mathrm{RC}_{50}$ 으로 하여 결과를 나타내고 저해율(inhibition rate or reduction concentration, \%)을 산출하였다.

\section{항암 활성}

실험에 사용된 암세포주는 모두 인체기원의 세포주로서, Korean Cell Line Bank(KCLB)로부터 구입한 폐암세포주인 Calu-6(ATCC, HTB-56)과 위암 SNU-601을 사용하였다. 세 포주의 배양은 $10 \% \mathrm{FBS}$ (fetal bovine serum)와 peniciline $\mathrm{G}(25 \mathrm{unit} / \mathrm{mL})$ 및 $\operatorname{streptomycin}(25 \mu \mathrm{g} / \mathrm{mL})$ 를 첨가한 RPMI 1640 배지를 사용하였으며 $37^{\circ} \mathrm{C}, 5 \% \mathrm{CO}_{2}$ 의 습윤화된 배양 기내에서 적응시켜 배양하였다. MTT(3-(4,5-dimethylthiazol2-yl)-2,5-diphenyl tetrazolium bromide) assay는 세포의 생육 상을 측정하는 방법 $(28,29)$ 으로서 살아 있는 세포의 미토콘 드리아 내의 dehydrogenase가 황색 수용성 물질인 MTT에 의해 dark blue formazon을 생성하는 원리를 이용한 것이다. 종양세포를 $3 \times 10^{4}$ cells $/ \mathrm{mL}$ 의 농도가 되도록 조절한 후 96 well microplate에 $90 \mu \mathrm{L} /$ well씩 분주하고 이것을 $37^{\circ} \mathrm{C}, 5 \%$ $\mathrm{CO}_{2}$ 세포배양기(Forma, Germany)에서 12시간 배양하여 세 포를 부착시킨 다음 추출물을 $50,100,200,400,800 \mathrm{mg} / \mathrm{kg}$ 농도가 되도록 $10 \mu \mathrm{L}$ 씩 첨가하였다. 대조군은 시료와 동일 한 양의 증류수를 첨가하여 동일한 조건으로 배양하였다. 이것을 검정에 가장 적합하다고 판단되는 기간인 72 시간 
동안 배양시킨 후, $5 \mathrm{mg} / \mathrm{mL}$ 농도로 조제한 MTT 용액을 각 well당 $10 \mu \mathrm{L}$ 씩 넣고 세포 배양기에서 4시간 동안 더 배양시킨 후, MTT 용액이 있는 배지를 제거하고 DMSO $150 \mu \mathrm{L}$ 를 첨가하여 30 분간 교반하여 각 세포를 용해시켜 microplate reader(Bio-Rad, USA)를 이용하여 $540 \mathrm{~nm}$ 에서 흡광도를 측정하여 그 값을 아래와 같이 각 세포의 시료 무첨가군을 $100 \%$ 로 하여 상대적인 세포 성장률을 환산하 였고, 억제정도가 $50 \%$ 일 때의 추출물의 농도를 $\mathrm{IC}_{50}$ 값으로 나타냈다.

암세포증식 억제효과 $(\%)=($ 대조구의 흡광도-시료처리구 의 흡광도)/대조구의 흡광도 $\times 100$

\section{통계분석}

모든 항목의 분석은 3 회 반복 실시하였으며 그 결과를 $\mathrm{SAS}(30)$ 를 이용하여 처리간의 평균치 차이는 $\mathrm{LSD}$ (Least significant difference) 검정을 통해 비교 · 분석하였다. 각 조사항목별 상관관계 $(\mathrm{p}<0.05)$ 를 알아보고자 총 페놀성 함 량, 총 안토시아닌 함량, DPPH 라디컬 소거능 및 세포독성 에 있어서 각 항목 양자 간의 상관계수를 도출하여 비교하 였다.

\section{결과 및 고찰}

\section{총 페놀성 함량}

Folin-Denis 방법에 따라 chlorogenic acid를 표준물질로 하여 분석한 석류 부위별 메탄올 추출물 농도 $1,000 \mathrm{mg} / \mathrm{kg}$ 에서 총 페놀성 함량을 정량한 결과, 고흥산 석류외과피에 서 $238.1 \mathrm{mg} / \mathrm{kg}$ 으로 가장 높았고, 주스와 종자는 각각 26.0 와 $23.2 \mathrm{mg} / \mathrm{kg}$ 으로 낮은 함량을 보였다(Table 1). 이와 같은 경향은 캘리포니아산에서도 유사하게 나타났으며 전체적 으로 고흥산(23.2 238.1 mg/kg)보다는 캘리포니아산(26.4

Table 1. Total phenolics content of methanol extracts at 1,000 $\mathrm{mg} / \mathrm{kg}$ from the fruit parts of pomegranate produced at Goheung and California

\begin{tabular}{ccccc}
\hline \multirow{2}{*}{ Region } & \multirow{2}{*}{ Fruit part } & \multicolumn{3}{c}{ Total phenolics level, mg/kg } \\
\cline { 3 - 5 } & & Catechin & Chlorogenic acid & Tannic acid \\
\hline \multirow{3}{*}{ Goheung } & Juice & $\left.19.4^{\mathrm{bl}}\right)$ & $26.0^{\mathrm{b}}$ & $14.3^{\mathrm{b}}$ \\
& Pericarp & $150.8^{\mathrm{a}}$ & $238.1^{\mathrm{a}}$ & $102.5^{\mathrm{a}}$ \\
& Seed & $12.8^{\mathrm{b}}$ & $23.2^{\mathrm{b}}$ & $9.2^{\mathrm{b}}$ \\
\hline \multirow{4}{*}{ California } & Juice & $23.2^{\mathrm{b}}$ & $28.2^{\mathrm{b}}$ & $18.4^{\mathrm{b}}$ \\
& Pericarp & $155.3^{\mathrm{a}}$ & $243.8^{\mathrm{a}}$ & $121.4^{\mathrm{a}}$ \\
& Seed & $18.8^{\mathrm{b}}$ & $26.4^{\mathrm{b}}$ & $14.7^{\mathrm{b}}$ \\
\hline
\end{tabular}

1)a-b Means with different superscripts within a column indicate significant differences $(\mathrm{p}<0.05)$.
$243.8 \mathrm{mg} / \mathrm{kg}$ )이 더 높게 나타났다. 이와 같은 경향은 다른 표준물질 catechin과 tannic acid에서도 같은 경향을 보였다.

Poyrazoglu 등(31)은 석류의 주스에서 총 페놀성화합물 외에도 개별 페놀산인 gallic acid, chlorogenic acid, caffeic acid, ferulic acid, $o$-와 p-coumaric acid 및 catechin 등이 다량 함유되어 있다고 보고한 바 있다.

\section{안토시아닌 함량}

석류 과실 부위에서 총 합산의 안토시아닌 함량을 기준 으로 고흥산 외과피 $(176.4 \mathrm{mg} / \mathrm{kg})$ 에서 가장 높은 함량을 보였고, 그 다음이 주스 $(52.2 \mathrm{mg} / \mathrm{kg})$ 였고, 종자 $(28.4 \mathrm{mg} / \mathrm{kg})$ 가 가장 낮은 함량을 보였다(Table 2). 고흥산 석류에서 가장 많은 함량을 보인 안토시아닌 색소는 $\mathrm{Cy} 3,5 \mathrm{G}$ 로 나타났고 그 다음이 Cy3G, Dp3,5G와 Pg3,5G 순으로 높았다. 한편, 캘리포니아산은 주스, 외과피, 종자 순으로 주스에서 총량 으로 $1,539.4 \mathrm{mg} / \mathrm{kg}$ 으로 가장 높은 함량을 보였고, 그 다음 이 외과피와 종자 순으로 각각 161.6 과 $68.7 \mathrm{mg} / \mathrm{kg}$ 으로 낮은 함량을 보였다. 가장 많은 함량을 보인 안토시아닌 색소는 역시 Cy3,5G로 나타났고 그 다음이 Dp3,5G, Cy3G와 Dp3G 순으로 높았다(Table 2). 과실 부위별 주요한 안토시아닌은 과육과 종자는 주로 $\mathrm{Cy} 3,5 \mathrm{G}$ 와 $\mathrm{Dp} 3,5 \mathrm{G}$ 중심으로, 외과피는 $\mathrm{Cy} 3,5 \mathrm{G}$ 와 $\mathrm{Cy} 3 \mathrm{G}$ 중심으로, 종자에서는 $\mathrm{Cy} 3,5 \mathrm{G}$ 와 $\mathrm{Dp} 3,5 \mathrm{G}$ 중심으로 높은 함량을 보였다. 따라서 지역간, 부위별 안토 시아닌 정성적 및 정량적인 차이는 뚜렷한 것으로 나타났다.

이는 Miguel 등(9)과 Song 등(24)의 연구에서 비록 본 연구와는 다른 석류 품종인 "Assaria" 및 "Wonderful" 과실 의 주스에서만 측정한 바 $\mathrm{Dp} 3 \mathrm{G}, \mathrm{Dp} 3,5 \mathrm{G}, \mathrm{Cy} 3 \mathrm{G}, \mathrm{Cy} 3,5 \mathrm{G}$, $\mathrm{Pg} 3 \mathrm{G}, \mathrm{Pg} 3,5 \mathrm{G}$ 가 검출되어 유사한 종류의 안토시아닌이 정 량되었으나 본 연구에서는 두 지역 석류의 부위별 안토시아 닌의 함량은 뚜렷한 차이를 보였다.

Table 2. Anthocyanin content of the fruit parts of pomegranate produced at Goheung and California

\begin{tabular}{|c|c|c|c|c|c|c|c|c|}
\hline \multirow{2}{*}{ Region } & \multirow{2}{*}{ Fruit part - } & \multicolumn{7}{|c|}{ Anthocyanin content, $\mathrm{mg} / \mathrm{kg}$} \\
\hline & & $\mathrm{Cy} 3,5 \mathrm{G}^{1)}$ & Cy3G & $\mathrm{Dp} 3,5 \mathrm{G}$ & $\mathrm{Dp} 3 \mathrm{G}$ & $\mathrm{Pg} 3,5 \mathrm{G}$ & $\mathrm{Pg} 3 \mathrm{G}$ & Total \\
\hline \multirow{3}{*}{ Goheung } & Juice & $17.2^{62)}$ & $4.9^{b}$ & $21.7^{\mathrm{a}}$ & $6.1^{\mathrm{a}}$ & $1.7^{\mathrm{b}}$ & $0.6^{b}$ & 52.2 \\
\hline & Pericarp & $71.2^{\mathrm{a}}$ & $54.1^{\mathrm{a}}$ & $7.5^{b}$ & $4.2^{b}$ & $20.2^{\mathrm{a}}$ & $19.2^{\mathrm{a}}$ & 176.4 \\
\hline & Seed & $11.3^{\mathrm{b}}$ & $2.8^{\mathrm{b}}$ & $10.1^{\mathrm{b}}$ & $2.8^{\mathrm{b}}$ & $1.0^{\mathrm{b}}$ & $0.4^{b}$ & 28.4 \\
\hline \multirow{3}{*}{ California } & Juice & $685.4^{\mathrm{a}}$ & $206.2^{a}$ & $449.9^{\mathrm{a}}$ & $135.0^{\mathrm{a}}$ & $42.8^{\mathrm{a}}$ & $20.1^{a}$ & $1,539.4$ \\
\hline & Pericarp & $78.5^{\mathrm{b}}$ & $22.8^{b}$ & $4.7^{\mathrm{b}}$ & $4.3^{b}$ & $38.0^{\mathrm{a}}$ & $13.3^{\mathrm{b}}$ & 161.6 \\
\hline & Seed & $25.4^{\mathrm{b}}$ & $7.6^{b}$ & $20.7^{b}$ & $7.3^{\mathrm{b}}$ & $4.0^{\mathrm{b}}$ & $3.7^{\mathrm{c}}$ & 68.7 \\
\hline
\end{tabular}

${ }^{11)}$ Cy3,5G, Cyanidin-3,5-diglucoside chloride; Cy3G, Cyanidin-3-0-glucoside chloride; Dp3,5G, Delphinidin-3,5-di-O-glucoside chloride; Dp3G, Delphinidin-3-O-glucoside chloride; Pg3,5G, Pelargonidin-3,5-di-glucoside chloride; Pg3G, Pelargonidin3-glucoside chloride.

2)arc Means with different superscripts within a column indicate significant differences $(\mathrm{p}<0.05)$. 


\section{항산화성}

석류 부위별 메탄올 추출물 $1,000 \mathrm{mg} / \mathrm{kg}$ 농도에서 $\mathrm{DPPH}$ 라디컬 소거능을 HPLC로 분석한 결과 외과피, 주스, 종자 순으로 외과피에서 활성이 가장 높게 나타났고, 종자에서 가장 낮게 나타났으며 캘리포니아산이 고흥산보다 약간 더 높은 활성을 보였다(Fig. 2). 특히, 두 지역의 외과피는 $62.5 \mathrm{mg} / \mathrm{kg}$ 농도에서 80.6 94.8\%로 높은 활성을 보인 반면, 종자는 6.8 11.3\%로 가장 낮게 나타났다.

석류 열매 에탄올 추출물 $12.5 \mathrm{mg} / \mathrm{kg}$ 농도의 DPPH 라디 컬 소거능은 외피, 씨, 과즙의 순서로 항산화 활성이 각각 $60.8 \%, 16.2 \%, 15.1 \%$ 로 우수한 것으로 보고한 박 등(32)의 보고와 일치하였다.

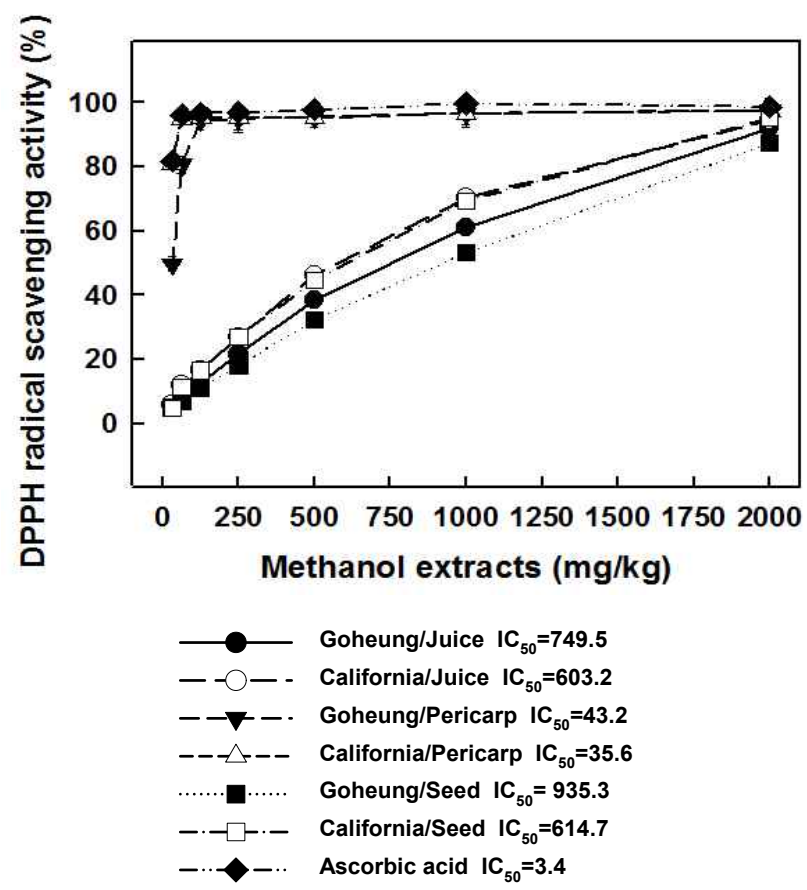

Fig. 2. Comparison in DPPH radical-scavenging activities of methanol extracts from juice, pericarp and seed of pomegranate (Punica granatum L.) fruit produced at Goheung and California. Their activities were compared with a synthetic antioxidant, ascorbic acid.

\section{항암 활성}

MTT assay에 의한 암세포주에 대한 세포독성 시험을 수행하였다. 석류 부위별 추출물 $800 \mathrm{mg} / \mathrm{kg}$ 농도까지의 Calu-6(폐암세포주)에 대한 세포생존율로 본 항암활성을 분석한 결과 외과피, 종자, 주스 순으로 각각 29.4 33.5, 63.6 68.5, 66.1 72.7\%로 나타나 외과피에서 활성이 가장 높게 나타났고, 종자에서 가장 낮게 나타났고 캘리포니아 산과 고흥산 모두에서 부위별 활성 차이가 뚜렷하였다 (Table 3).

SNU-601(위암세포주)에 대한 항암활성은 Calu-6에 대한
활성보다 낮았으나 주스, 외과피, 종자 순으로 각각 50.3 52.6, 52.6 58.2, 62.5 66.1\%로 나타나 주스에서 활성 이 가장 높게 나타났고, 종자에서 가장 낮게 나타났으며 캘리포니아산과 고흥산 모두에서 부위별로 다른 활성을 보였다(Table 4).

박 등(32)도 간암세포 HepG-2에 대한 석류 추출물 2,500 $\mathrm{mg} / \mathrm{kg}$ 처리구에서 주스(43\%), 종자(42\%), 외과피(38\%) 순 으로 높은 성장억제율을 보인 것으로 밝힌 바가 있으나, 본 연구 결과에서는 폐암 및 위암 세포주에 대해 비교적 더 높은 활성을 보여 암세포주 간에도 차이가 있음을 확인 할 수 있었다.

Table 3. Cytotoxic effect of the methanol extracts from pomegranate fruit parts on a human cancer cell line, Calu- 6 for human pulmonary carcinoma

\begin{tabular}{cccccc}
\hline \multirow{2}{*}{ Region } & \multirow{2}{*}{ Fruit part } & \multicolumn{4}{c}{ Extract concentration, mg/kg } \\
\cline { 3 - 6 } & & 100 & 200 & 400 & 800 \\
\hline \multirow{3}{*}{ Goheung } & Juice & $75.1^{\mathrm{a} 1)}$ & $75.0^{\mathrm{a}}$ & $74.6^{\mathrm{a}}$ & $72.7^{\mathrm{a}}$ \\
& Pericarp & $73.8^{\mathrm{a}}$ & $70.8^{\mathrm{a}}$ & $39.3^{\mathrm{c}}$ & $33.5^{\mathrm{c}}$ \\
& Seed & $72.6^{\mathrm{a}}$ & $72.2^{\mathrm{a}}$ & $63.6^{\mathrm{b}}$ & $63.6^{\mathrm{b}}$ \\
\hline \multirow{3}{*}{ California } & Juice & $70.4^{\mathrm{a}}$ & $68.3^{\mathrm{a}}$ & $65.2^{\mathrm{a}}$ & $66.1^{\mathrm{a}}$ \\
& Pericarp & $63.3^{\mathrm{b}}$ & $60.4^{\mathrm{b}}$ & $34.7^{\mathrm{b}}$ & $29.4^{\mathrm{b}}$ \\
& Seed & $75.1^{\mathrm{a}}$ & $74.2^{\mathrm{a}}$ & $70.4^{\mathrm{a}}$ & $68.5^{\mathrm{a}}$
\end{tabular}

1)acc Means with different superscripts within a column indicate significant differences $(\mathrm{p}<0.05)$.

Table 4. Cytotoxic effect of the methanol extracts from pomegranate fruit parts on a human cancer cell line, SNU-601 for human gastric carcinoma

\begin{tabular}{cccccc}
\hline \multirow{2}{*}{ Region } & Fruit part & \multicolumn{4}{c}{ Extract concentration, mg/kg } \\
\cline { 3 - 6 } & & 100 & 200 & 400 & 800 \\
\hline \multirow{3}{*}{ Goheung } & Juice & $66.2^{\mathrm{all}}$ & $65.8^{\mathrm{a}}$ & $61.8^{\mathrm{a}}$ & $52.6^{\mathrm{c}}$ \\
& Pericarp & $68.2^{\mathrm{a}}$ & $65.83^{\mathrm{a}}$ & $64.4^{\mathrm{a}}$ & $58.2^{\mathrm{b}}$ \\
& Seed & $66.7^{\mathrm{a}}$ & $66.1^{\mathrm{a}}$ & $64.4^{\mathrm{a}}$ & $62.5^{\mathrm{a}}$ \\
\hline \multirow{4}{*}{ California } & Juice & $60.2^{\mathrm{b}}$ & $55.8^{\mathrm{b}}$ & $52.4^{\mathrm{b}}$ & $50.3^{\mathrm{b}}$ \\
& Pericarp & $66.2^{\mathrm{a}}$ & $65.8^{\mathrm{a}}$ & $61.8^{\mathrm{a}}$ & $52.6^{\mathrm{b}}$ \\
& Seed & $70.4^{\mathrm{a}}$ & $68.3^{\mathrm{a}}$ & $65.2^{\mathrm{a}}$ & $66.1^{\mathrm{a}}$ \\
\hline
\end{tabular}

${ }_{\text {1)arc }}$ Means with different superscripts within a column indicate significant differences $(\mathrm{p}<0.05)$.

각 관련 성분과 항산화성 또는 항암활성 항목간의 상관 관계를 알아본 결과, 총 페놀성 함량과 Calu-6 폐암세포주 활성 간이 $\mathrm{r}^{2}=0.9706$ 으로 가장 높았고, 그 다음이 총 페놀성 함량과 DPPH 라디컬 소거능 간, DPPH 라디컬 소거능과 Calu-6 폐암세포주 활성 간 순으로 상관계수( $\left.\mathrm{r}^{2}\right)$ 가 각각 0.8904, 0.8309로 나타났다(Table 5). 이는 메탄올 추출물에 대한 DPPH 라디컬 소거능은 총 페놀성 함량의 높은 상관이 
있다는 보고들(33,34)과 유사한 경향이었다. 한편, 총 안토 시아닌 함량이 DPPH 라디컬 소거능, SNU 위암세포주 활성 에 영향을 주는 상관계수는 매우 낮은 것으로 나타났다. 결국, 총 페놀성 함량의 생리활성물질이 Calu-6 폐암세포주 에 대한 활성과 DPPH 라디컬 소거능에 미치는 상관계수는 매우 높아 상호간에 높은 상관성이 있음을 알 수 있었다 (Table 5).

본 연구는 석류의 부위별 항암활성에 대해 MTT-assay라 는 고전적인 방법을 통해 in-vitro 시험에 국한된 한계점이 있으며 이를 극복하기 위해 차후 활성을 보인 추출물과 분획물을 목표로 보다 정밀한 in-vivo 차원의 시험연구가 수반되어야 할 것으로 사료된다.

Table 5. Correlation coefficients among physiologically-active components and their bio-activities of fruit parts of pomegranate produced at Goheung and California

\begin{tabular}{cccccc}
\hline & $\mathrm{TP}^{1)}$ & $\mathrm{TA}$ & $\mathrm{DPPH}$ & Calu-6 & SNU \\
\hline TP & 1.0000 & 0.0444 & 0.8904 & 0.9706 & 0.0463 \\
TA & & 1.0000 & 0.0001 & 0.0314 & 0.3097 \\
DPPH & & & 1.0000 & 0.8309 & 0.0671 \\
Calu-6 & & & & 1.0000 & 0.0305 \\
SNU & & & & & 1.0000 \\
\hline
\end{tabular}

${ }^{1)} \mathrm{TP}$, total phenolic content; TA, total anthocyanin content; DPPH, DPPH radical scavenging activity; Calu- 6 , anticancer activities on human pulmonary carcinoma; SNU, human gastric carcinoma.

p-values of $<0.05$ were considered significant.

\section{요 약}

고흥산과 캘리포나이산의 석류나무(Punica granatum L.) 과실을 과육, 종자 및 외과피로 분리하여 부위별 총 페놀성 함량, 안토시아닌 함량, DPPH 라디컬 소거능에 대한 항산 화 활성 및 항암활성을 비교 - 검토하였다. 석류과실의 총 페놀성 함량은 외과피>주스>종자 순으로 유의적인 차이로 높게 나타났다. DPPH 라디컬 소거능은 외과피>주스>종자 순으로 높았고, 특히 외과피의 항산화 활성은 vitamin $\mathrm{C}$ 와 유사한 활성을 보였다. 폐암세포주(Calu-6)에 대한 추출물 의 항암활성은 외과피>종자>과육 순으로 높게 나타났다. 고흥산 석류 과실 부위별 총 안토시아닌 함량은 외과피>주 스>종자 순으로 나타났고, 함유된 주요 안토시아닌은 $\mathrm{Cy} 3,5 \mathrm{G}$ 로서 가장 높은 함량을 보였고 그 다음이 $\mathrm{Cy} 3 \mathrm{G}$, $\mathrm{Dp} 3,5 \mathrm{G}$ 순으로 높게 나타났다. 총 페놀성 함량과 Calu-6 폐암세포주 활성 간이 $\mathrm{r}^{2}=0.9706$ 으로 가장 높았고, 그 다음 이 총 페놀성 함량과 DPPH 라디컬 소거능 간, DPPH 라디컬 소거능과 Calu-6 폐암세포주 활성 간 순으로 상관계수 $\left(\mathrm{r}^{2}\right)$ 가 각각 $0.8904,0.8309$ 로 나타나 상호 연관이 있음을 나타냈 다.

\section{감사의 글}

본 논문은 2016학년도 광주여자대학교 교내연구비 지원 에 의하여 연구되었음(KWUI 16-057).

\section{References}

1. Park JH (2005) Korean reduction pictorial book, Shinil, Seoul, Korea, p 257-260

2. Kim HK, Noo CY, Jung BM, Ha YD, Shin YK (1994) In: The pomegranate cultivation fact-finding survey and fine variety (The cultivation of fruit tree and quality improvement research), The agricultural development administration report, $\mathrm{p}$ 448-450

3. Guo CJ, Yang JJ, Wei J, Li YF, Xu J, Jiang YG (2003) Antioxidant activities of peel, pulp and seed fractions of common fruits as determined by FRAP assay. Nutrition Research, 23, 1719-1726

4. Li YF, Guo CJ, Yang JJ, Wei J, Xu J, Chung S (2006) Evaluation of antioxidant properties of pomegranate peel extract in comparison with pomegranate pulp extract. Food Chem, 96, 254-260

5. Negi PS, Jayaprakasha GK, Jena BS (2003) Antioxidant and antimutagenic activities of pomegranate peel extract. Food Chem, 80, 393-397

6. Bae PC (2001) The oriental medicine previous, The traditional medical science research institute, Seoul, $p$ 130-145

7. Kim SH (2005) The health functional food in the world. The drinking water newspaper company, Seoul, $p$ 119-121

8. Choi OK, Chung KS, Cho GS, Hwang MO, Yoo SY (2002) Proximate compositions and seleated phytoestrogens of lranian black pomegranate extract and its products. Korean J Food Nutr, 15, 119-125

9. Miguel G, Fontes C, Antunes D, Neves A, Martins D (2004) Anthocyanin concentration of "Assaria" pomegranate fruits during different cold storage conditions. J Biomed Biotechnol, 2004, 338-342

10. Lansky EP, Newman RA (2007) Punica granatum (pomegranate) and its potential for prevention and treatment of inflammation and cancer. J Ethnopharmacol, 109, 177-206

11. Moon GS (1991) The ingredient of the medicinal plant and use. Ilwol books, Seoul, p 59

12. Kim CM, Shin MG, Lee GS, Ahn DK (1998) The Chinese 
medicine great dictionary. Jungdam publish company, Seoul, p 2391-2394

13. Jin SY (2007) Antioxidant activity in pomegranate and development of the Maejakgwa added pomegranate extract. MS Thesis, Sookmyung Women's University, Korea, p 1-160

14. Choi SY, Lim SH, Kim JS, Ha TY, Kim SR, Kang KS Hwang IK (2005) Evaluation of the estrogenic and antioxidant activity of some edible and mechanical plants. Korean J Food Sci Technol, 37, 549-556

15. Ozcal N, Dinc S (1993) Evaluation of the pomegranate (Punica granatum L.) peels from the standpoint of pharmacy. Eczacilik Fakültesi Dergisi, 22, 21-29

16. Jahfar M, Vijayan KK, Azadi P (2003) Studies on a polysaccharide from the fruit rind of Punica granatum. Res J Chem Environ, 7, 43-50

17. Park TG (2005) The food and health. The public employee annuity management corporation, Seoul, $\mathrm{p}$ 35-37

18. Yoo HK (2005) Antioxidative effects and phytoestrogenic activities of ethanol extracts from pomegranate seeds. $\mathrm{Ph}$ D Thesis, Chungang University of Korea, p 8-9

19. Gil MI, Tomas-Barberan FA, Hess-Pierce B, Holcroft DM, Kader AA (2000) Antioxidant activity of pomegranate juice and its relationship with phenolic composition and processing. J Agric Food Chem, 48, 4581-4589

20. Schubert SY, Lansky EP, Neeman I (1999) Antioxidant and eicosanoid enzyme inhibition properties of pomegranate seed oil and fermented juice flavonoids. J Ethnopharmacol, 66, 11-17

21. Tran, HNA, Song BH (2005) Existence of a-eleostearic acid in pomegranate seed oil and its binding activity against ERa \& ERß. Proceeding of The Korean Society of Medical Crop Science International Symposium, 13, 205-206

22. Tran HNA, Yoon SH, Bae YS, Song BH (2005) Effect of punicic acid in pomegranate seed oil to the human breast cancer cell proliferation. Proceeding of The Korean Society of Medical Crop Science International Symposium, 13, 203-204
23. Fatope MO, Al Burtomani SK, Takeda Y (2002) Monoacylglycerol from Punica granatum seed oil. J Agric Food Chem, 50, 357-360

24. Song BH, Song KS, Kim JG, Kim, YH, Seu YB, Ghim, SY, Lee, JM, Kim SH (2005) Development of functional food using reinforced antioxidants and phytoestrogens from Punica granatum. Final Report for ARPC Project Ministry of Agriculture, Seoul, Korea, 19-100

25. Singleton VL, Rossi JA (1965) Colorimetry of total phenolics with phosphomolybdic-phosphotungstic acid reagents. Am J Enol Vitic, 16, 144-158

26. Hiemori M, Koh E, Mitchell AE (2009) Influence of cooking on anthocyanins in black rice (Oryza sativa L. japonica var. SBR). J Agric Food Chem, 57, 1908-1914

27. Blois MS (1958) Antioxidant determinations by use of a stable free radical. Nature, 26, 1199-1200

28. Mosmann T (1983) Rapid colorimetric assay for cellular growth and survival: application to proliferation and cytotoxicity assays. J Immunol Methods, 65, 55-63

29. Choi JS, Park SH, Kim IS (1989) Studies on the active principles of wild vegetables on biotransformation of drug. Kor J Pharmacogn, 20, 117-122

30. SAS (2000) SAS/STAT user's guide. Version 7, Electronic Version, Cary, NC, USA

31. Poyrazoglu E, Gokmen V, Artik N (2002) Organic acids and phenolic compounds in pomegranates (Punica granatum L.) grown in Turkey. J Food Comp and Anal, 15, 567-575

32. Park KT, Kim DW, Sin TS, Shim SY, Kim MY, Chun SS (2009) The effects of pomegranate extracts on the growth inhibition against HepG-2 liver cancer cells and antioxidant activities. Korean J Culinary Research, 15, 120-127

33. Sun J, Chu YF, Wu XZ, Liu RH (2002) Antioxidant and antiproliferative activities of common fruits. J Agric Food Chem, 50, 7449-7454

34. Zhou K, Yu L (2006) Total phenolic contents and antioxidant properties of commonly consumed vegetables grown in Colorado. LWT-Food Sci Technol, 39, 1155-1162 